\title{
Robert Dahl: scholar, teacher, and democrat
}

\section{Citation}

Hochschild, Jennifer. 2015. “Robert Dahl: Scholar, Teacher, and Democrat." Journal of Political Power 8 (2) (May 4): 167-174. doi:10.1080/2158379x.2015.1055943.

\section{Published Version}

doi:10.1080/2158379X.2015.1055943

\section{Permanent link}

http://nrs.harvard.edu/urn-3:HUL.InstRepos:30403712

\section{Terms of Use}

This article was downloaded from Harvard University's DASH repository, and is made available under the terms and conditions applicable to Open Access Policy Articles, as set forth at http:// nrs.harvard.edu/urn-3:HUL.InstRepos:dash.current.terms-of-use\#OAP

\section{Share Your Story}

The Harvard community has made this article openly available.

Please share how this access benefits you. Submit a story.

Accessibility 
Robert Dahl: Scholar, Teacher, and Democrat

Jennifer Hochschild

March 14, 2015

DRAFT v2: prepared for a special issue of the Journal of Political Power, edited by David Baldwin and Mark Haugaard, forthcoming 2015.

Like so many of his students and colleagues, I am proud and even grateful (a term we do not use much) to describe Robert Dahl as a teacher, intellectual model, and eventually friend. ${ }^{1}$ His was a life of civic and political activity, transformative scholarship, influential teaching, university leadership, and an overall level of integrity and decency that few people - perhaps especially, few scholars - can match. This journal issue attests to Dahl's importance, as did the broad public attention to his death. And for good reason: he exemplified the democratic citizen and did more than perhaps any other writer in the last half of the twentieth century to shape debates over what democracy is and should be.

Dahl's body of work influenced my generation of political scientists so deeply that it is hard to sort out where his Impact lay; we breathe his air. Let me first describe his intellectual strengths, then examine one notable flaw. Both are illuminating.

The first striking feature of Dahl's work is analytic. He taught us how to think about what a political system needs in order to be democratic, different ways a society might organize itself and plausibly be democratic, and how components of a democracy work together or stymie one another. A democratic political system might follow James Madison's constitutional logic, in which powerful groups and institutions offset one another so that no faction gets too much control and so that the government has little chance of accruing too much power (the high school civics notion of checks and balances, or "ambition countering ambition" in Madison's words). Alternatively, a democratic political system might be populist, making it easier for majorities to get their way in policy design and implementation, but risking threats to the rights or interests of minorities.

Or, in the definition that Dahl preferred, a genuine democracy must have the social arrangements and norms that enable all people to participate and all groups and

1 It gives me pleasure to note that I am one of only two political scientists, to my knowledge, who has been to Skagway, Alaska--population 920 in 2010-- where Dahl grew up. (The other is Stephen Wasby.) A small indicator of his personality is the fact that he went out of his way to talk with my parents, then living in Alaska, about Skagway when they visited me at Yale.

Thanks to C. Anthony Broh, David Mayhew, Cynthia Verba, Sidney Verba, and an anonymous correspondent (see page XXX) for helpful comments. 
ideas to compete freely and fairly. That implies some stringent conditions-freedom of movement, speech, and association; a robust press or other channels of information; frequent, free, and fair elections with genuine alternatives; sufficient resources held by members of the public so they feel free to think and act as they please; limits on the potentially overweening power of corporations and other huge organizations, and more. As his radicalism deepened through his career and as he grew more disillusioned about the workings of governments, Dahl eventually declined to call any existing political system a democracy. Since no actual society has sufficient participation and effective contestation, even the most admirable only rise to the level of being polyarchies (Dahl 1971).

That point implies another crucial element of Dahl's research and teaching: one must carefully study what is actually happening in governance to determine how democratic a city or country really is. If that seems self-evident, it is because we are so influenced by Dahl's writing. Before his most famous book, Who Governs? (Dahl 2005), much scholarship on democracy focused on constitutional structures, laws and formal procedures, or theories of class domination. Too often, an argument received support mainly from anecdotes, historical analogies, deep conviction, sheer ego, or narrowly construed investigations.

In contrast, Dahl and a few other scholars promoted a systematic behavioral revolution-turned-mainstream (Dahl 1961). He and his students chose the small city of New Haven for a case study, immersing themselves in the minutiae of how a mayor and his associates govern: Who gets to choose the next aldermanic candidates? Who gets to decide where the housing project will be built? What does the school board do? How does a leader acquire or lose influence? How do a city's Notables interact with its Plebes, both in one period and over generations or even centuries? Power, in this view, does not exist unless one can observe and enumerate $A$ getting $B$ to do something that $B$ would not otherwise do - none of this airy nonsense about penumbras, potential influence, unspoken control, or mental domination [(Dahl 1957); (Dahl 1958)].

I teach Who Governs? as the first book in my favorite course, on "Power in American Society." The smart and assertive students love to tear into it, showing how it is naïve, incomplete, outdated, insufficiently rigorous, complacent. But the careful readers among them come to see that Dahl anticipated and dealt with most of their objections. They discover how difficult it is to refute his core assertion that a reasonably well functioning political system can give everyone the opportunity to have at least a little political impact. Above all, Who Governs? shows what one can do when a powerful analytic theory about the meaning of democracy is unobtrusively melded into a careful, even pedantic-seeming, study of politics on the ground.

Dahl's implicit call for a moral or normative underpinning for one's research was the final crucial element of his impact. He was both an instinctive and an intentional egalitarian, reverting to the radicalism of his youth as he grew older. By the 1980s, while a majority of Americans were moving to the political and economic right, Dahl became more and more insistent that without much greater material equality, political equality was impossible. He asserted, for example, the necessity of workers' ownership 
or control of large firms: "if democracy was justified in governing the state, then it must also be justified in governing economic enterprises; and to say that it is not justified in governing economic enterprises is to imply that it is not justified in governing the state." This was published at the mid-point of the Reagan presidency.

Near the end of his life, Dahl once again explored the meaning of equality and its centrality to any democratic project. In arguably his strongest prose ever (Dahl 2003), he excoriated the American Constitution for creating a political structure that denies equal participation and contestation to all citizens. He called on Americans to rethink the conditions necessary for a genuine democracy, compared the United States unfavorably with other polyarchies, and proposed his own constitutional and statutory reform. Intellectually at least, he did not go gently into that good night.

Because what I see as Dahl's major scholarly flaw is so closely linked to his singular virtues, I now turn to an examination of one important blind spot in his body of writing. Despite his commitment to equality and the dignity of all, many publications were insufficiently attentive to the most serious failure of American democracy-- its history of slavery, apartheid, and arguably continued second-class citizenship of many African Americans. Who Governs? and perhaps my favorite of his essays, "On Removing Certain Impediments to Democracy in the United States" (Dahl 1977), both demonstrate this blind spot, and also provide lessons from which all scholars can benefit.

The first quarter of Who Governs? examines the transition in political power from the patricians of the late eighteenth century to the ex-plebes, "rising out of the workingclass or lower middle-class families of immigrant origin," by the middle of the twentieth century. "This change-one might properly call it a revolution-appears to be a profound alteration in the ways political resources are distributed among the citizens of New Haven." It created an all-important "shift from cumulative inequalities. . . to noncumulative or dispersed inequalities" (all quotations in this paragraph on p. 11). The rest of the book traces the ways in which these dispersed inequalities create a roughand-ready democracy (what Dahl might later have characterized as a local polyarchy). Citizens can attain at least a small share of political power if they try hard enough, they can influence a crucial policy decision if they organize and expend slack resources, they can have an impact on one or another arena of governance. Citizens are linked by a shared belief in democratic norms and practices that exercise crucial restraints on power-holders even when more honored in the breach than the observance. Overall, this is a reasonably optimistic, gratifying portrayal of inevitably flawed people and institutions behaving decently and fairly.

And yet, published in 1961, Who Governs? almost completely missed the racial dynamics of New Haven, a city that exploded in riots and protests a few years later. Index entries provide an artificial but telling indicator of the book's attention. "Ethnic" has eight entries, many with multiple pages, and the index entry further directs the reader to "See also Germans, Irish, Italians, . . Russians [and Immigration]"-each of which identifies an additional set of up to a dozen entries. By comparison, the ellipsis in the previous sentence directs the reader to "Negroes," which offers five entries. 
More revealing than a simple count is the way in which Who Governs? generally points to racial issues. "Race" or "racial" appear several times in the index, but almost always the entry points to a list that includes other societal divisions. For example:

! "member of a particular interest group, social stratum, neighborhood, race, ethnic group, or profession" (p. 93);

! "Nor have I seen any issues that you could call racial or religious issues," in a quotation from "an unusually tough-minded informant" (p. 149);

! "social standing, religion, ethnic origin, or racial stock" (p. 226);

! "That regional, ethnic, racial, religious, or economic differences might disrupt the American political system has been a recurring fear among the political stratum" (p. 318).

Dahl quotes a sociologist on the "socio-biological axis of race" in New Haven, with "two social worlds. . .- -a Negro world and a white world." This expert's revealing start continues, however, by exploring divisions among whites, and says nothing more about Negroes (p. 234). Dahl does not comment or add his own gloss.

A caveat is essential here. Who Governs? does point to race-based discrimination; in almost the last chapter, Dahl observes that "probably the most significant group in New Haven whose opportunities are sharply restricted by social and economic barriers are Negroes" (p. 293). He points to residential segregation - "although they are gradually dispersing"-- employment discrimination--although "discrimination is declining"--and poverty (p. 293). But Who Governs? turns away from racial hierarchy after a few paragraphs, developing instead, with data analyzed over several pages, an argument that "in local politics and government the barriers are comparatively slight." Negroes vote and are more politically active than comparable whites, they are the objects of party competition, they suffer no discrimination in public employment, they always have a representative on the Board of Aldermen and in one city-wide office.

In short, race (by which Dahl usually though not always meant a difference between all blacks and all whites) and racial hierarchy certainly appear in Who Governs? But with rare exceptions, race plays no distinct role in the narrative; as the index entries and lists above show, the division between blacks and whites usually has the same or even less linguistic and analytic status as the division between Irish and Italians or between Protestants and Catholics. More deeply, Dahl's central agenda in Who Governs? is to show the political implications of the "revolution" that occurred with the dispersal of resources from the patricians to the ex-plebes. The book's underlying contention is that, although social, economic, political inequalities persisted in the late 1950s, they were not structural, rigid, or impermeable. In that way, New Haven could reasonably be understood to represent "democracy itself" (p. xv).

Urban redevelopment was one of Dahl's three case studies for determining who actually governs, and it could have been the setting for probing the racially biased features of New Haven's politics and policy-making. But it was not. Given redevelopment's status as "the central policy of his [Mayor Lee's] administration" ( $p$. 121), Dahl attends carefully to the creation and maintenance of a favorable political coalition, and shows how this policy initiative reinforced Lee's power and capacity for 
leadership. His purpose, that is, was "not an appraisal of the desirability of the program but an attempt to understand the political forces that shaped it" (p. 115). Thus although Dahl points out that "by 1959 much of the center of the city was razed to the ground," he never hints at the viewpoint that became prominent a few years later, of urban renewal as "Negro removal."

We need more context to make sense of Dahl's treatment of race and urban renewal. On the one hand, Negroes were "a relatively small though increasing minority," comprising less than 10 percent of the population and concentrated in only a few wards (p. 293). Irish and Italian ethnics were much more numerous and much more consequential to New Haven's politics and policy-making. And almost no one with political influence or public visibility perceived a racial problem in northern cities before the 1960s; virtually everyone during the 1950s perceived job or housing discrimination to be private issues. To my knowledge, no prominent political actor pointed out in the 1950 s that the razing of "slums" might make their residents worse off than before, reinforcing blacks' segregation, powerlessness, and alienation. In fact, as Dahl points out, one of Mayor Lee's "action committees" set up to promote redevelopment "was made up in great measure of social workers, liberals, clergymen, Negro leaders, housing officials, and religious leaders" (p. 134).

On the other hand, the black population in New Haven was indeed increasing, and rapidly. African Americans comprised 5.8 percent of the city's population in 1950, 14.5 percent in 1960 , and 26.3 percent in $1970 .{ }^{2}$ And racial dynamics looked very different a few years after Who Governs? was published: "the late 1960s were chaotic in New Haven, CT. Marches, demonstrations and rioting with large scale arson were the norm. Not every day of course but most of it got to be routine." ${ }^{3}$ Within a few years of Who Governs?' publication, urban renewal was understood to be profoundly racialized, and observers began noting that displaced blacks were being scattered or simply left to fend for themselves in increasingly expensive urban rental markets [(Thomas 2013); (Schuyler 2002); (Connolly 2014)].

In short, with the clarity of hindsight, one can see the solidification in the 1950s -when Who Governs? was being researched and written-- of racial gaps in northern cities that were different in kind, not just in magnitude, from the gaps among white ethnic or religious groups. As Douglas Rae puts it, "the timing of the black migration to New Haven [in the 1950s and 1960s] was an economic horror; if the goal was to capture high-wage manufacturing jobs in and near central-city neighborhoods. . . the timing couldn't have been worse" (Rae 2003), 258). Furthermore, post-war public housing and urban renewal policies were reinforcing the older residential segregation established through municipal zoning and federal studies of "neighborhood security." Looking back at 1950s New Haven, Rae could point to "the intense marginalization of black ghettos" and "spatial hierarchy as [an] enduring institution" (Rae, 2003, 280; see chaps. 8, 10). None of this appears in Who Governs?

2 http://www.census.gov/population/www/documentation/twps0076/CTtab.pdf

3 Observation from AP photographer David Vine, at https://www.youtube.com/user/davidvine 
What lessons should we draw, beyond agreeing with Yogi Berra that "It's tough to make predictions, especially about the future"? One lesson is intellectual humility. One can never tell when a research program or publication will be overtaken by history, such that the hapless author can look foolish or shortsighted in retrospect. Colleagues of mine wrote learnedly about the long term stability of the USSR or East Germany; other colleagues wrote about the ways in which Arab Spring would democratize the Middle East and North Africa; I wrote an essay explaining how the 2008 United States' presidential election would usher in a new policy regime of racial and economic equalization. Looking back, we can point to suggestive evidence that Dahl missed or cognitive blinders that someone as smart as he should have been able to overcome. But if even he was unable to see a crucial failure of pluralist democracy, how much more should the rest of us avoid certitude about the issues on which we claim to be experts? (Tetlock 2005).

A second lesson is methodological, or even epistemological. One of Dahl's former students reports that the research team for Who Governs? debated how to make race more prominent in the analysis. After all, protests both for and against civil rights reforms were prominent in the 1950s, and "Dahl was involved in various activities at the national level. So it seemed odd to us that race was not more salient in the New Haven study." But given their rigorously empirical methodology, racial division appeared to play little role in the accrual and exercise of political power.

Thus the very strength of Who Governs?' empirical method also turned out to be a weakness. By insisting on overt, measurable, empirical manifestations of the operation of power and influence, Dahl left out the kind of supremacy that whites held over blacks that was so strong as to be invisible in the quotidian dealings of political New Haven. This point is not new, of course; Peter Bachrach and Morton Baratz long ago asserted the importance of "nondecisions" (Bachrach and Baratz 1962), and Steven Lukes and others have further explored the second, third and fourth faces of power [(Lukes 2004); (Gaventa 1980); (Isaac 1987)]. But it is always worth reminding ourselves that the more powerful our research method or analytic lens, the greater the risk that it leaves out something crucially important, awareness of which might profoundly change an argument.

The third lesson has an element of irony. Dahl wrote so clearly and systematically that Who Governs? provides most of the tools needed for its critique. The book defines crucial terms such as influence and pluralist democracy, explains alternative patterns of leadership, instructs readers on how to study power and its uses, arrays evidence from archives to case studies to surveys and aggregated data, and articulates its broadest normative reach. A less rigorous thinker or less disciplined prose are arguably harder to criticize since the target can be obscured. The lesson for us readers is that scholarship advances more by seriously engaging with the best work of those with whom one disagrees than by picking easy marks or piling up support for one's own position.

"On Removing Certain Impediments to Democracy in the United States" offers the second, and more troubling, source of material for engaging with Dahl's inattention to racial hierarchy. It is an essay, not a major research project like Who Governs? Nonetheless, it shows the same great ability to organize concrete evidence in the service of large, important conclusions underlain by strong normative commitments. 
"On Removing. . ." identifies five periods of consequential political decision-making in the United States' history; before each period, "alternative possibilities seemed open to the principal historical actors, who, however, were in conflict over the relative desirability of the alternatives they perceived." After each period, "what had recently been a sharply contested possibility ... came to be accepted as pretty much an undebatable aspect of the status quo" (p. 2).

The five periods are the commitment to a liberal political and constitutional order around 1800 , a democratic political system by 1836 , corporate capitalism by 1900 , a federal welfare state in the 1930s, and involvement in the international arena as a world power in the 1940s. Without doubt these are all crucial turning points, and Dahl brilliantly lays out the choices available before each decision and their impact on American democracy, as well as their cumulative consequences for political and economic equality. But one obviously important moment is missing: the preservation of the Union and abolition of slavery in the 1860s.

Even if I were not a scholar of racial politics, the omission is startling. Surely the Civil War and the $13^{\text {th }}, 14^{\text {th }}$, and $15^{\text {th }}$ Amendments were a turning point in the eyes of any historically knowledgeable scholar; many textbooks and courses, for example, are divided into the two halves of antebellum and postbellum. But for someone as passionate about equality, democracy, and human dignity as Dahl undoubtedly was, to leave out the 1860s in a list of crucial inflection points in American history raises questions.

Dahl's writing did engage more with issues of racial hierarchy toward the end of his life, especially in How Democratic is the American Constitution?, published in 2003. The first of the seven ways in which the American Constitution "fell far short of the requirements. .. necessary and desirable in a democratic republic" is slavery (p. 15). The second failure was the suffrage, given that it took almost 200 years for the federal government to pass an effective voting rights law. The fifth failure was equal state representation in the Senate, which "failed to protect the fundamental rights and interests of the most deprived minorities" and gave "some strategically placed and highly privileged minorities - slaveholders, for example--. . . disproportionate power." (p. 18). Abolition of slavery was one of "the most important amendments to the Constitution," (p. 175), just as slavery was "the most profound violation of human rights permitted by the original constitution" ( $p X X)$, given the "deep wounds that slavery and its aftermath inflicted on human equality, freedom, dignity, and respect."(p. 125).

Dahl always knew how profoundly racial hierarchy violates the norms and institutions that he most cherished. But in most of his work, as "On Removing. .." makes very clear, he focused on other dimensions of inequality, primarily economic and political. Thus he came late to incorporating his knowledge of racial injustice into the core of his research and writing. This uncomfortable fact points to the fourth and most important lesson to emerge from considering his treatment of American racial hierarchy: the need for personal as well as intellectual humility. Dahl knew his own worth and was not falsely humble; his courtesy and kindness had a tinge of noblesse oblige. But he was also a genuine democrat and egalitarian, intellectually honest and willing to learn from his students. I once gathered my courage and asked why he had not included the 1860s in "On Removing. ..." He answered simply that he had been wrong and wished that he could rewrite chapters or articles, that one in particular. 
If a scholar as great as Dahl continued to miss over a long period of time what now seems like a central element of his own deepest concerns, how much more vulnerable are the rest of us? I conclude that we need to be very careful about our focus on some issues to the exclusion of others, our willingness to castigate the flaws of our predecessors, our moral and empirical certitudes -- lest fifty years from now some commentator points out blind spots and embarrassments in our own published record.

I learned many things from Robert Dahl; I miss him deeply.

\author{
References
}

Bachrach, Peter and Morton Baratz (1962). "Two Faces of Power." American Political Science Review 56 (4): 947-952.

Connolly, Nathan (2014). A World More Concrete: Real Estate and the Remaking of Jim Crow South Florida Chicago IL, University of Chicago Press.

Dahl, Robert (1957). "The Concept of Power." Behavioral Science 2 (3): 201-215.

--- (1958). "A Critique of the Ruling Elite Model." American Political Science Review 52 (2): 463-469.

--- (1961). "The Behavioral Approach in Political Science: Epitaph for a Monument to a Successful Protest." American Political Science Review 55 (4): 763-772.

--- (1971). Polyarchy: Participation and Opposition. New Haven CT, Yale University Press.

--- (1977). "On Removing Certain Impediments to Democracy in the United States." Political Science Quarterly 92 (1): 1-20.

--- (2003). How Democratic Is the American Constitution? Second Edition. New Haven $\mathrm{CT}$, Yale University Press.

--- (2005). Who Governs? Democracy and Power in an American City, Second Edition New Haven CT, Yale University Press.

Gaventa, John (1980). Power and Powerlessness : Quiescence and Rebellion in an Appalachian Valley. Urbana, University of Illinois Press.

Isaac, Jeffrey (1987). Power and Marxist Theory: A Realist View Ithaca NY, Cornell University Press.

Lukes, Steven (2004). Power: A Radical View, 2nd Ed. London, Palgrave Macmillan.

Rae, Douglas (2003). City: Urbanism and Its End. New Haven CT, Yale University Press. 
Schuyler, David (2002). A City Transformed: Redevelopment, Race, and Suburbanization in Lancaster, Pennsylvania, 1940-1980. University Park PA, Pennsylvania State University Press.

Tetlock, Philip (2005). Expert Political Judgment: How Good Is It? How Can We Know? Princeton NJ, Princeton University Press.

Thomas, June (2013). Redevelopment and Race: Planning a Finer City in Postwar Detroit Detroit MI, Wayne State University. 